\title{
Landscape, Geopolitics, and National Identity in the Norwegian Thrillers Occupied and Nobel
}

\author{
Robert A. Saunders \\ Department of History, Politics and Geography, Farmingdale State College - SUNY, USA
}

\begin{abstract}
Focusing on the use of landscape in the Norwegian series Occupied (2015-2020) and Nobel (2016), this article examines the ways in which cityscapes and panoramas of the natural environment are employed as affective, as well as aesthetic tools for storytelling within a geopolitically inflected framework. Drawing on literature from popular geopolitics, geocriticism, and visual politics, my analysis interrogates the ways in which geopolitical codes and visions manifest via televisual fiction, reflecting a variety of insecurities associated with Norway's current position in world affairs, as well as contemporary challenges to Norwegian national identity. This article also discusses how these two series have adapted key geovisual elements of the what I deem the "near Nordic Noir" style to focus more explicitly on geopolitical questions, linking Occupied and Nobel to other geopolitically inflected series from Nordic Europe.
\end{abstract}

Keywords: landscape, Nordic Noir, geopolitics, Occupied, Nobel

\section{Introduction: Screening geopolitics in the "North"}

Dramatic television series are increasingly delving into complex geopolitical themes, from the premediation of a female prime minister in Borgen, to the critique of USRussian relations in the Middle East in House of Cards, to allegorical depictions of climate change in Game of Thrones. The renowned scholar of popular culture and world politics Daniel Drezner (2016) has commented that we live in a "golden age" of international relations (IR) television programming, one where past, present, and imaginary metaphorical worlds abound. With their increasing focus on pressing contemporary issues in IR (or revisionist approaches to historical geopolitical conflicts) and attention to detail - via themes, characters, objects, and settings - the meticulously built worlds of series like The Bridge, Berlin Station, and Deutschland 83 offer the viewer realms to explore, and - more importantly - to imagine themselves in (see Saunders, 2019b). Driven by the proven profitability of such fare, there is a growing list of series that place questions of world politics at the core of their narratives, using not only plots, but also

Saunders, R. A. (2020).Landscape, geopolitics, and national identity in the Norwegian thrillers Occupied and Nobel. Nordicom Review, 41(Special Issue 1), 63-83. https://doi.org/10.2478/nor2020-0006 
settings - especially screened natural and human-built environments - to tell geopolitical tales. Even fantastical series such as the Netflix offerings Stranger Things, Dark, and 1983 fold world politics into their storytelling, using the Cold War as a starting point for sculpting their impossible-yet-disturbingly-familiar imaginaries.

Connecting all the aforementioned series is a privileged place for landscape and its attendant ideological moorings and symbolic power (see Cosgrove, 1984; Lefebvre, 2007b; Lukinbeal, 2005; Woodward, 2014). Thus, as I argue in this article, television is now emerging as a space for viewing the land as part of national identity production (and consumption) - especially given that "the impact of place and locality in narrative media can be regarded as seminal for the medium's function of communicating culture and negotiating societal discourses" (Eichner \& Waade, 2015: 1). As in earlier flurries of landscape production, whether in the form of paintings in the mid-nineteenth century or via film during the twentieth century, the current televisual turn towards landscape serves as an indispensable element of meaning-making in a world in transition. Thus, this intervention provides an original contribution by critically assessing the use of place-based imagery in relation to geopolitics and IR, therein going beyond extant scholarship focused on landscape as a televisual tool that supports character development, visualises the intended mood, and serves other aesthetic ends (cf. McElroy \& Noonan, 2019; Hansen \& Waade, 2017; Roberts, 2016). As a "repository of meanings and associations", television series - and especially geopolitical dramas - serve as toolkits "from which people can draw to make sense of innovation and their consequences" in the world around them (Turner et al., 2014: 988).

Keeping with the scope of this special issue, this article focuses on the use of landscape in the Norwegian series Okkupert [Occupied] (TV2, 2015-2020) and Nobel-fred for enhver pris [Nobel - freedom at any price], referred to in English only as Nobel (NRK, 2016), and landscape's attendant influence on geopolitical understandings both in Norway and beyond. Building on research into the evolving medium of IR-inflected television (cf. Dyson, 2015; Glynn \& Cupples, 2015; Kiersey \& Neumann, 2013; Moïsi, 2016; Saunders, 2019b) and seconding Roberts's (2016: 364) call to "put landscape more firmly in the frame of critical television studies [emphasis original]", I examine the ways in which cityscapes and panoramas of the natural environment are employed as affective - as well as aesthetic - tools for storytelling within geopolitically inflected frameworks.

Geopolitics, while a constitutive element of IR, highlights the importance of place and space in determining power relations between states, thus privileging geographic settings and perspectives in relation to political processes (Cohen, 2003). Drawing on literature from popular geopolitics, geocriticism, and visual politics, my analysis examines the ways in which geopolitical codes and visions manifest in television series via the visual rhetoric of screened landscapes. Reflecting on the etymological foundations of the pan-Germanic linguistic concept of "landscape" (i.e., land + shape), I am particularly interested in the ways in which depictions of various "scapes" (Appadurai, 1996) address distinct insecurities associated with Norway's current position in world affairs, as well as contemporary challenges to Norwegian national identity. With this intervention, I expand on Roberts's framework for engaging the "spectator's perception [of the] spaces that constitute what is within and (by negation) what lies beyond the frame" (2016: 367); I do this by linking such gazing to everyday understandings of world politics. Informed by recent work that combines popular cultural production and surveillance studies (Bos, 2018; Dodds, 2011; 
Zimmer, 2015), I introduce the notion of "scoping" via technological enhancements of the "militarised, machinic eye" (Dyer-Witherford \& De Peuter, 2008) as a technique that expands, refines, and (dis)orients the use of landscape in screened interventions (e.g., film, television, videogames, etc.). My approach is also girded by the concept of the "scopic regime", which was originally identified by Metz (1982: 61) as a specifically cinematic technique which is not about the "distance kept" but more about the "absence of the object seen", thus unhinging what is seen from its "real" referent (see also Jay, 1988).

Given the medium of analysis (i.e., television), my focus is quite literally on the ways in which the viewer's gaze is concentrated on meaningful spatial imageries via a double lens; here, I refer to the cinematographer's camera coupled with a secondary mechanism for "seeing" (such as a sniper rifle's scope, satellite imagery, drone video feed, etc.), a technique that has become commonplace in contemporary police, crime, and spy drama (see Turner et al., 2014). Twinned with Appadurai's (1996) metaconcept of "scaping", which helps us understand the disjunctures and differences of global culture, especially via mediated formats, I interrogate how these two series have adapted particular geovisual elements of what I deem the "near Nordic Noir" style. In doing so, I focus more explicitly on geopolitical questions and various dimensions of (state) power, linking Occupied and Nobel to such fare as Borgen (2010-2013), Blue Eyes (2014), and Below the Surface (2017-), each of which exemplifies the growing trend towards the geopoliticisation in "serious television". Via the tentative frameworks of scaping and scoping, I also examine how these two series' "spatial spectacles" (Hansen \& Waade, 2017: 89) sculpt geopolitical and geographic imaginaries of Norway, while also conveying "various mythical sediments that layer and frame" the ways in which spaces are consumed outside their countries of origin (Lefebvre, 2007b: xv).

While the study of landscape in television series in still in its ascendancy, the importance of landscape in cinema is well established (cf. DeLue \& Elkins, 2008; Harper \& Rayner, 2010; Lefebvre, 2007b; Mitchell, 2002; Roberts, 2012b). As the foundational element of setting, landscapes - whether those depicting wild spaces bereft of human activity, claustrophobic urban realms overflowing with people, or an idyllic main street in Middle America - inform the motivations of the characters, shape the narrative, and create the mood. As I have discussed elsewhere, the depiction of landscape is never neutral, and typically relies on the viewer's (often jaundiced) geopolitical understanding of place; moreover, "failure to aesthetically produce an intelligible 'place' will result in a disconnect that will undermine the final cultural product" (Saunders, 2017: 188). Thus, landscape - in its screened depictions - instrumentalises place (Roberts, 2016), moulding it to the needs of cultural production. In the aesthetic representation of this place or that place, ideologically inflected assemblages of information are conveyed without a single word of dialogue being uttered. As Roberts (2012a: 68) informs us in his analysis of screened landscapes, "The idea that film could function as a map, indeed even be a map itself is not new", and, in that revelation, it becomes clear that cultural producers are also cartographers whose "maps" help us make sense of (geo)politics.

Following Cohen (2003), I do not simply utilise geopolitics as a synonym for international politics, but instead focus on the ways in which political power is linked to geography, and how spatiality informs the interplay between people, territory, and resources, while also shaping hierarchies, alliances, and rivalries in the world system. As a scholar of IR, I am naturally more interested in the geopolitical implications and instru- 
mentality of landscape in television series, rather than its function vis-à-vis production values or contributions to the international attractiveness of a particular series. Nordic television fiction, and particularly its noir and near-noir forms, is on the bleeding edge of this transformation. The genre has swept the world due to its complex storytelling, flawed characters, aesthetic qualities, and attention to detail, especially when it comes to depictions of place and space. As I argue below, landscapes in Nordic Noir are - in and of themselves - geopolitical interventions. According to the Nordic Noir journalist Annika Pham (personal correspondence, 26 August 2017):

\begin{abstract}
Nature and landscapes [play] a very important role in the success of Nordic noir as the settings are often dramatic, and the threatening elements in the plot are underlined by dark and rainy skies, cold and icy landscapes. Nature in general in particular in Norway with the deep forests and fjords, and in Iceland with the volcanic bare landscape and glaciers - is hostile to human beings. Men [sic] are isolated, cut [off] from the world, and of course, this makes it for perfect crime material, with characters having to fight enemies against tough natural elements.
\end{abstract}

Going beyond the artistic merits of landscapes, the choices that showrunners make about how to represent space and place serve specific geopolitical agendas. This should come as no surprise to television scholars. Unlike the vast majority of American and British productions, series from Denmark, Sweden, Norway, Finland, and Iceland tend to receive significant levels of public funding, which comes with the informal stipulation the content serves the nation in some way. Often this service comes via an ethical quandary or social critique and referred to as "double storytelling", meant to unsettle the viewer and preclude complacency in the building of a better society (Redvall 2016: 43). Rooted in a culturo-religious traditions associated with northern European polities (e.g., in-group collectivism, modesty, egalitarianism, etc.) and informed by historical social democratic political orientations, such content need not valorise the state; in fact, even the most cursory overview of Nordic Noir will reveal more in the way of criticism than accolades, typically using the crime to unmask governmental or corporate malfeasance. As Mrozewicz (2018: 33) argues, Nordic Noir - drawing on the Scandinavian crime fiction which preceded it - emphasises the state as a "centre of evil", highlighting the harm it does to "individuals, especially its own citizens". The genre takes aim at the seemingly "perfect democratic Scandinavian models", instead depicting them as "cracked mirrors" which reveal and refract a "deeper malaise in society that touches everyone and [thus] appeals to a global audience" (Personal correspondence with Annika Pham, 26 August 2017). Despite receiving public funds, Nordic Noir is not propaganda - far from it. Series such as Iceland's Stella Blómkvist (2017-), Denmark's Follow the Money (2016), Sweden's Midnight Sun (2016), and Finland's Deadwind (2016-) all produce indictments of the state and society; and, in each of these instances, the landscapes that define Norden are operationalised as part of the narrative. With that, I now move to a brief précis of landscapes in the "North" before shifting to an analysis of my two case studies.

\title{
The "North" and landscape - historical perspectives
}

Landscape - in its original, most orthodox form - is a northern European innovation (cf. Lefebvre, 2007a; Norberg-Schulz, 1996; Roberts, 2016). The term - which brings 
together the components of the "land" and the idea of "shape" or "constitution" (Olwig, 2004) - is used across all major Germanic languages. Key examples include the Swedish and Norwegian landskap, the Danish landskab, the Icelandic landslag, the German Landschaft, and the Dutch landschap, from which the English term was borrowed in the early seventeenth century. As a realm defined by the "early fading of the light" and "a place of dearth", landscapes of septrional Europe differ from those of the Mediterranean world. They combine physical geography with the "essence of the idea" of the north (Davidson, 2005: 20-21), historically informing what sorts of land-shapes are most iconic in the production of national identity. While a somewhat analogous concept exists in the languages of southern and eastern Europe, the linguistic structuration is slightly different. Being based on variants of the French paysage or "view" of the "countryside", terms such as the Italian paesaggio, the Spanish paisaje, the Romanian peisaj, the Russian пейзаж, and the Turkish peyzaj lack the epistemologically important notion of "scaping" (Appadurai, 1996); instead, these terms convey a meaning of "setting" or representation, therein lacking the northern adjunct of perception (Lefebvre, 2007a: 20), as well as the "self-referential circulation of reference" wherein the landscape shapes its own "representation image" (Olwig, 2004: 42). ${ }^{1}$ Landscapes, originally rendered via etchings and paintings, proved foundational in the establishment of national identities connected to the "land" in northern European states during the nineteenth century. Infused with a panoply of influences drawn from sources as diverse as pre-Christian mythology, apocryphal travelogues, and folk ballads, artists of various religious, philosophical, and ideological persuasions trundled into the countryside and set their brushes to work creating nations (see Gunnarsson, 1998).

Figure 1. Nordkapp [North Cape] by Peder Balke (1845)

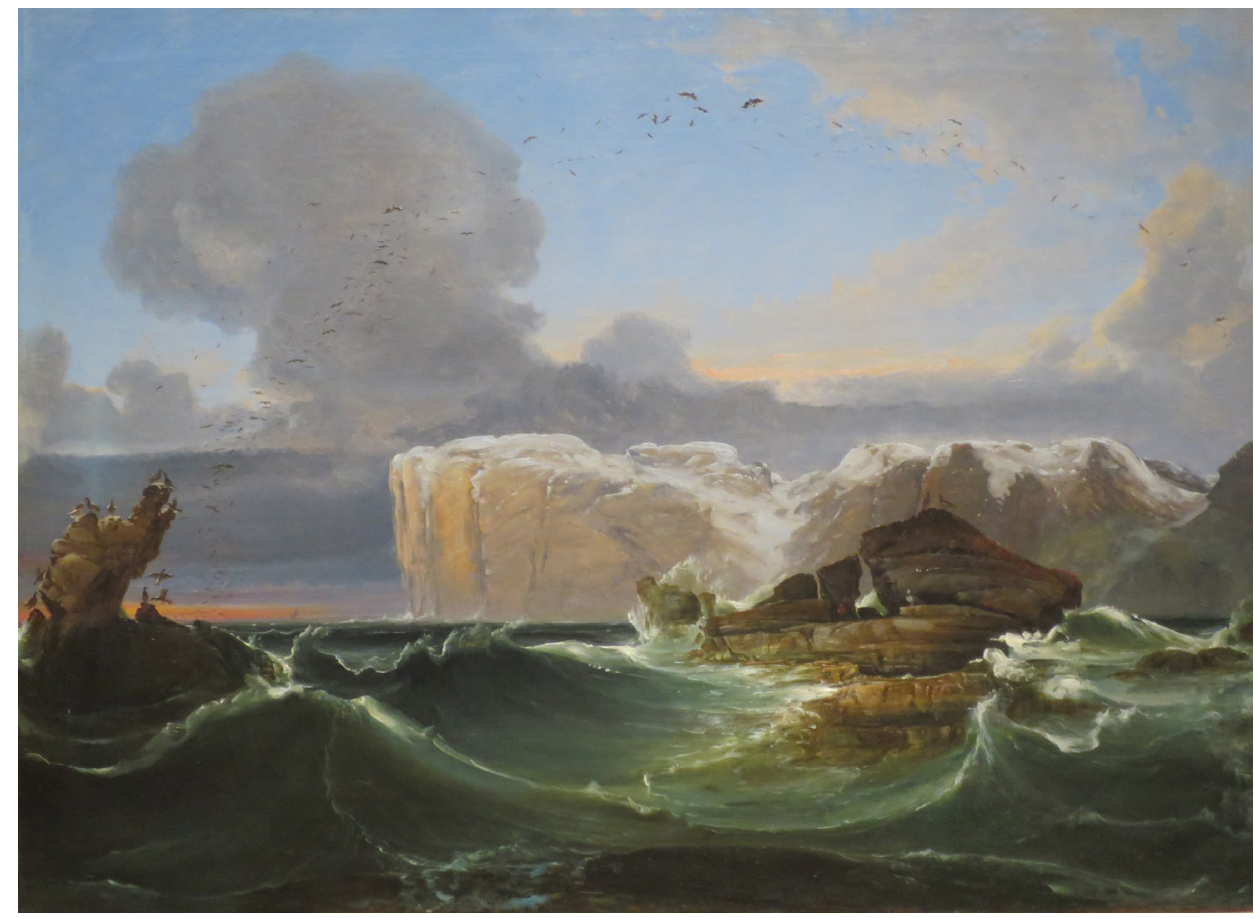

Source: Wikimedia Commons 
Emblematic examples of such nation-building landscape paintings include Caspar David Friedrich's Kreidefelsen auf Rügen [Chalk Cliffs on Rügen] (1818), Peder Balke's Nordkapp [North Cape] (1840) (see Figure 1), and Pekka Halonen's Talvimaisema Myllykylästä [Winter Landscape] (1896). Some northern polities enjoyed storied histories as state formations (England, Denmark, the Netherlands, and Sweden), while others were nations in waiting (Germany, Norway, Finland, and Iceland). Regardless, the various peoples of the upper half of the European continent soon came to view the artist's canvas as a palimpsest upon which identity could be performed, while nationalist elites saw a vehicle for achieving their (geo)political aspirations. Over time, a raft of new media interventions allowed for landscapes to be transmitted to domestic (as well as foreign) audiences, from simple sketches reproduced in the pages of daily broadsheets to the revolutionary platform of moving pictures. As Lefebvre (2007b: xiii) points out: "Landscape is a multifaceted and pluridisciplinary spatial object whose meanings and representations extend from real-life environment to art". Indeed, landscape paintings emerged as key techne for establishing national difference, with the Nordic countries serving as the most important sites of such activity; and, as Norberg-Schulz (1996: 11) argues, it is in Norway that we find the "strongest and most immediate" manifestation of nature as the nation. In defence of his argument, he goes on to state of his homeland:

A text of 1777 describes Norway as one enormous rock, riven with valleys. This image is accurate, for there is scarcely another country united to such a degree by mountains [...] Norwegian spatial structure is as different from the Danish as possible. Here, one lives not in an extensive, open environment but between high walls; and although Norway is larger and more vigorous than its southern sister, it seems smaller because it lacks prospect. (Norberg-Schulz, 1996: 30-31)

Not surprisingly, Norwegian nationalists frequently turned to "historico-topographical accounts" showcasing their homeland as the "birthplace of giants, with its wintry landscape, hills, rocks, and peaks" to (favourably) cast their "liberty-loving" co-nationals' characteristics against those of the collectivist, lowland Danes (Elviken, 1931: 370-373). Expounding on what differentiates Norwegians from their Nordic counterparts, Booth (2015: 178) notes that they are "defined by their landscapes to the way that the French are defined by their culture", particularly in their names which are "connected to the landscape". This manifests in Occupied (discussed below), especially through its protagonist Jesper Berg, whose surname translates as "mountain".

Spanning the tundra of Finnmark and Svalbard, the endless fjords of the North Sea Coast, the evergreen forests of upper Telemark, and the lowlands of Østfold, Norway's physical geography provides a multivalent cornucopia of northern spaces to be rendered in artistic representations. As a country that came into being - at least in its current form - little more than 100 years ago (Norway is considered established as a fully sovereign state when its union with Sweden, in place since 1814, dissolved in 1905), Norway is defined by its "natural resources - minerals, fjords, forests, waterfalls" and its "thinly spread communities" (Woolridge, 2013b: para. 2). As a relative latecomer to the western European community of states, Norway has leaned heavily on its land as an argument for why it should also be an independent nation, with "certain landscapes" coming to be seen as a "vital missing element of the modern present" (Fyhri et al., 2009: 202). Landscapes thus serve as a "shrine to the past" (see Lowenthal, 1982) that hark back to 
the Middle Ages when Norse conquerors spread out across Europe, carrying with them tales of the elemental geographies from whence they came. Indeed, two millennia of cultural production about Scandinavia and its mountainous northwestern fringe only served to reinforce the power of nature in shaping life in Ultima Thule (see Dodds, 2018). However, we should also consider the importance of non-aristocratic forms of land ownership in late nineteenth-century Norway as an emotive aspect of proprietary or propertied nationalism that privileged one's personal plot of land as part of a larger congeries that strengthened the ethnos and polity (see Fuglestad, 2018). Given the scope of this analysis, it is also relevant to note that the putative founder of geopolitics, political scientist Rudolf Kjellén, forged his arguments about the "biological” nature of nation-states with examples rooted in Sweden's dominion over Norway, later going on to support the German Reich's influence across Europe during the Great War and later inspiring the Nazi-era school of Geopolitik (cf. Agnew, 1998; Herwig, 2016; Ó Tuathail, 1996).

Returning to the theme of landscape, whether we speak of the Aurora Borealis emerging over the Scandes, the thousands of kilometres of rugged coastline, or the humanbuilt environment of Oslo, Norway is bound to its various (mountain-, sea-, city-, etc.) "scapes". In this structuration, the Norwegian subject or citizen is thus situated as part of a greater natural world, one which includes the earthen, inanimate, and stationary (mountains, valleys, rocks, beaches), elemental spaces of movement and growth (rivers, seas, glaciers, trees, fields), built environments (streets, harbours, cabins, houses, castles, apartment blocks), and mobile creatures (wolves, reindeer, horses, bees, birds, fish, whales, other humans). However, there is a dark and unseen force that stalks this idyllic gestalt - oil. As I explore below, the boon of North Sea petroleum has weighed heavily on Norway's Selbstbild [self image] since the 1960s, metaphorically polluting the hitherto pristine view of Norway as the natural reserve of Europe's far north (see Rees, 2016). Just as the landscape paintings relied on rendered oils to realise the "land-view" as conceived by the artist and gazed upon by the public, today it is hydrocarbon sales that (at least partially) fund the creative industries in Norway, including the televisual output of public and private broadcasters like NRK and TV2. As Roberts (2016) has argued, Nordic Noir television series - particularly in their close and studied screening of the North and "Northernness" - are a post-millennial evolution of landscape's visual rhetoric, one which informs and advances narratives of the nation, especially through television's ability to frame the "Other". So, by conceiving of television viewing as an "affective act of world-building" that should be viewed a part of the "discursive battlefield of global politics" (Saunders, 2019a), the land that we view matters.

\section{Occupied - imagining Norway under siege (once again)}

Based on an idea by the Norwegian crime novelist Jo Nesbø, and created by Erik Skjoldbjærg and Karianne Lund, Occupied premiered as Norway's most expensive original television series to date. When the first episode aired on Norway's TV2, more than 50 per cent of viewers 20-49 years old tuned in, making the show a huge success (Melton, 2016). Direct distribution soon followed in the UK, Germany, France, Sweden, Denmark, Finland, Iceland, Serbia, Estonia, Poland, Czech Republic, Belgium, the Netherlands, Luxembourg, and Spain. Recently concluding its third season, Occupied is available 
for streaming via Netflix in the UK, Ireland, Australia, New Zealand, India, Canada, Belgium, Sweden, the Netherlands, and - of course - the US, where it is rumoured to be the platform's most popular import from Nordic Europe (Ellis, 2018).

The series revolves around the rise of the Green Party following a devastating hurricane that hits the Scandinavian country, a real-world event that is briefly featured in the programme's opening credits (Hurricane Maria wreaked havoc on the country in 2005). Operating with a clear mandate, the new prime minister, Jesper Berg (Henrik Mestad), enacts a sweeping pro-environment agenda. He begins with the cessation of all fossil-fuel production due to climate change, thus poignantly screening the predicted outcome of The Economist's special report on the Nordic countries which stated that Norway - despite its hydrocarbon riches - is "preparing for its post-oil future" (Woolridge, 2013a: para. 7). Although Norway plans to offset the looming energy crisis with the development of thorium-based nuclear energy, the European Union (EU) roundly condemns the policy shift, subsequently signalling to the Kremlin that the bloc would support the Russian Federation's "assistance" in restarting oil and natural gas output in the North Sea. Washington, as the viewer learns, has withdrawn from its collective security treaties following the achievement of energy independence, thus eerily premediating both the US's solidification of its position as the world leader in energy production and President Donald Trump's attacks on NATO as "obsolete" (quoted in Hains, 2016). Indeed, Nesbø's dark ruminations on the future of the transatlantic alliance have not gone unnoticed, as a number of more recent reviews of the series have shown (cf. Dyson, 2018; Rapoza, 2017; Wolcott, 2016).

Not surprisingly, the theme of geographical and geopolitical isolation pervades Occupied, often "put in the frame" via calculated screenings of space and place that, under the influence of Nesbø's vision, echo his homeland's precarity during World War II, while also highlighting Norway's geographic and geopolitical marginality within Europe (Norway is not a member of the EU). Such positionality is reinforced by visual rhetoric, which showcases the harsh beauty of the country. Landscapes of the northern realms are rooted in a tenuous balance between life and death (Dodds, 2018), a truism that emerges in the opening scenes of Occupied as Prime Minister Berg is witness to a murder that stains the pristine snow red with blood against a backdrop of evergreen trees. Following the kidnapping and release of the prime minister by un-uniformed Russian security personnel, a velvet glove operation ensues. Norway's sovereignty steadily ebbs under the increasing influence of the Russian ambassador Irina Sidorova (Ingeborga Dapkūnaite) and the rising tide of covert Russian migration into the country. The narrative centres on a member of the Norwegian Politiets sikkerhetstjeneste [police security service], Hans Martin Djupvik (Eldar Skar), who wins the trust of the Russians following his thwarting of an assassination attempt on Sidorova within the walls of the Akershus Fortress (for a view of Oslo from the Akershus Fortress, see Figure 2). While balancing the challenges of his home life (his wife is a judge who is compromised by his unexpected infamy), Djupvik plays a complex game, winding his way through his bosses in government, anti-Russian insurgents, Ambassdor Sidorova, and her superiors back in Moscow. Two other key characters include the restauranteur Bente Norum (Ane Dahl Torp) and her journalist husband, who find themselves on opposite sides of the political divide in the country. The Telegraph (2017) describes the series as such: "Startlingly prescient in the wake of the Paris Agreement and Russia's recent military excursions, 
this effortless geopolitical thriller imagines a nation beset by oil-hungry neighbours and a creeping domestic invasion". Subsequent seasons of Occupied expand the scope of the drama, focusing on trans-Baltic efforts to curtail Russian influence (season 2) and a partial restoration of Norwegian sovereignty as part of an EU-brokered deal requiring a resumption of oil and natural gas production (season 3 ).

Figure 2. A view of central Oslo from the Akershus Fortress

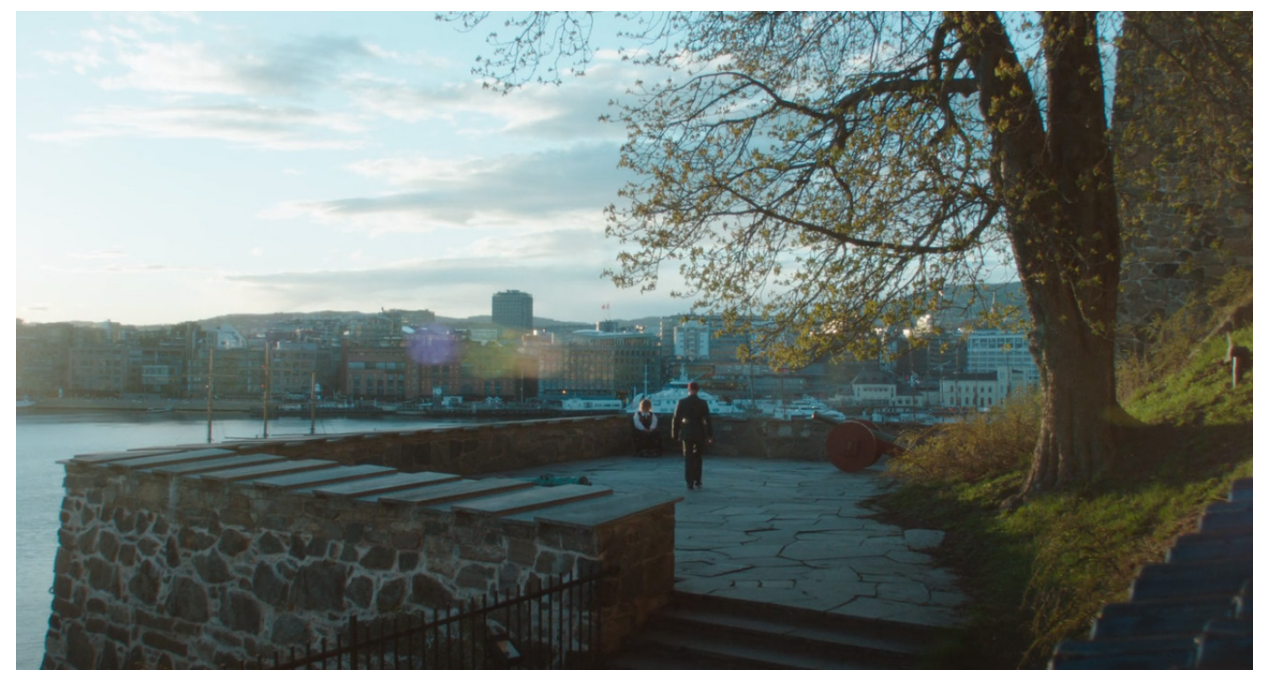

Source: Occupied/Yellowbird

Vivid depictions of landscapes proliferate in Occupied, placing it squarely within the growing suite of cli-fi (climate fiction) programming that includes other Nordic series like Fortitude (2015-), Trapped (2015-), and Jordskott (2015-) (see also Souch, in this issue). The dramatic opening credits showcase the impact of a powerful storm on the country, aurally framed by the English-language song "Black \& Gold" by the Norwegian recording artist Sivert Høyem (2015). The anthem recounts the proud Viking past of the Norwegian people, extolling their intrepid spirit before turning to the issue of oil exploitation in the chorus:

\section{Welcome to the seaside \\ It's been occupied \\ Burrow to the bottom \\ And behold! - The mother lode \\ Of black and gold}

Linking greed, resources, and fate, the use of the song presents the viewer with a biting critique of the country's dependence on fossil fuel wealth; this as they are witness to a cascade of images depicting an extreme weather event that destroys homes, endangers citizens, and hobbles the economy, thus laying bare Booth's assertion that "black gold touches every Norwegian's life, pretty much in every way" (2015: 180). Promotional material for the French- and German-language broadcasts of the series made this explicit, with separate images of the main characters, each in profile, framed by a seascape defined by an oil rig, and with the lower halves of their bodies melting into crude 
(metaphorically "dripping" into and thus polluting the North Sea). In its advertisements, Netflix conspicuously used a grey-scale image of Berg and Djupvik with their lower bodies forming a canvas showing an offshore platform looming over the oceanic horizon; similar promotional imagery accompanied the Australian broadcast of the series (see also Mrozewicz in this issue).

Using genuine footage of storm surge and flooding in Norway, the credits end with an ominous dark grey seascape, obviously intending to provoke a chilling effect - and affect - with the viewer. Occupied's inaugural season one episode "April" opens in the hills above Oslo, with a stunned Berg wandering along a snow-covered logging road amongst the evergreens and looking down at the blood-stained ice - the cost of his own mitigation of his country's "petro-guilt" (Rees, 2016). The pristine quality of the landscape contrasts with the (implied) violence, as does the prime minister's outfit (he is in a suit without any overcoat), thus suggesting that something has gone horribly wrong. As we learn, the prime minister has been abducted and threatened while on board a helicopter; upon landing, an innocent passerby who spotted the prime minister is shot and killed (along with his dog), thus explaining the claret on the snow. The evocative use of the Norwegian countryside continues throughout the series, becoming a space where those actors who resist the coming Russian invasion take refuge to plan for the ultimate victory over the aggressor. However, in the interim, other important landscapes and "land-scopings" - via the machinic eye that becomes the aperture through which the viewer gazes upon the scene - are deployed to construct the geopolitical tableau upon which Occupied plays out. Important instances include the (fictional) seat of democratic power (actually the iconic Fornebu offices of Statoil; see Figure 3) and the fantastical arboreal laboratory where thorium is set to save the world from humankind's thirst for energy (both of which effortlessly link the natural and human-built worlds), as well as various technologically abetted "God's eye views" of the country showing Russian military manoeuvres.

Interestingly, the counterpoising of these aforementioned sites makes a subtle, yet trenchant invocation of Norwegian territory. In the use of the Statoil building as the ersatz offices of the head-of-government, the showrunners link the Norwegian state to petroleum production, but then quickly pivot to another image wherein global sustainability is in reach via thorium. Named for the Norse god of thunder, and discovered by the amateur mineralogist Hans Morten Thrane Esmark on the island of Løvøya, thorium is framed by Occupied as a particularly Nordic response to the Anthropocene, one which links the geopolitical to the geological. ${ }^{2}$ The importance of genius loci thus bleeds through both these landscape depictions, with the existential threat of anthropogenic global climate change framing Occupied's metanarrative, which concludes with Berg breaking the fourth wall and calling on environmental activists to strike at governments to hold them accountable for the costs of rampant neoliberalism.

The geopolitical and the geoeconomic are likewise depicted in subsequent scenes, from the attempted assassination of the Russian ambassador within the walls of the Akershus Fortress to the false-flag terror attack on a refining facility supplying continental Europe. As it becomes clear that the Russian Federation "assistance operation" is becoming a permanent proposition, those loyal to a free Norway (literally, the name of the resistance group Fritt Norge) embrace the wilderness, seeking safety in the land itself. This conceit, at least in some ways, inverts the norms of new Nordic Noir wherein 
Figure 3. Fornebu offices of Statoil qua Norway's seat of power

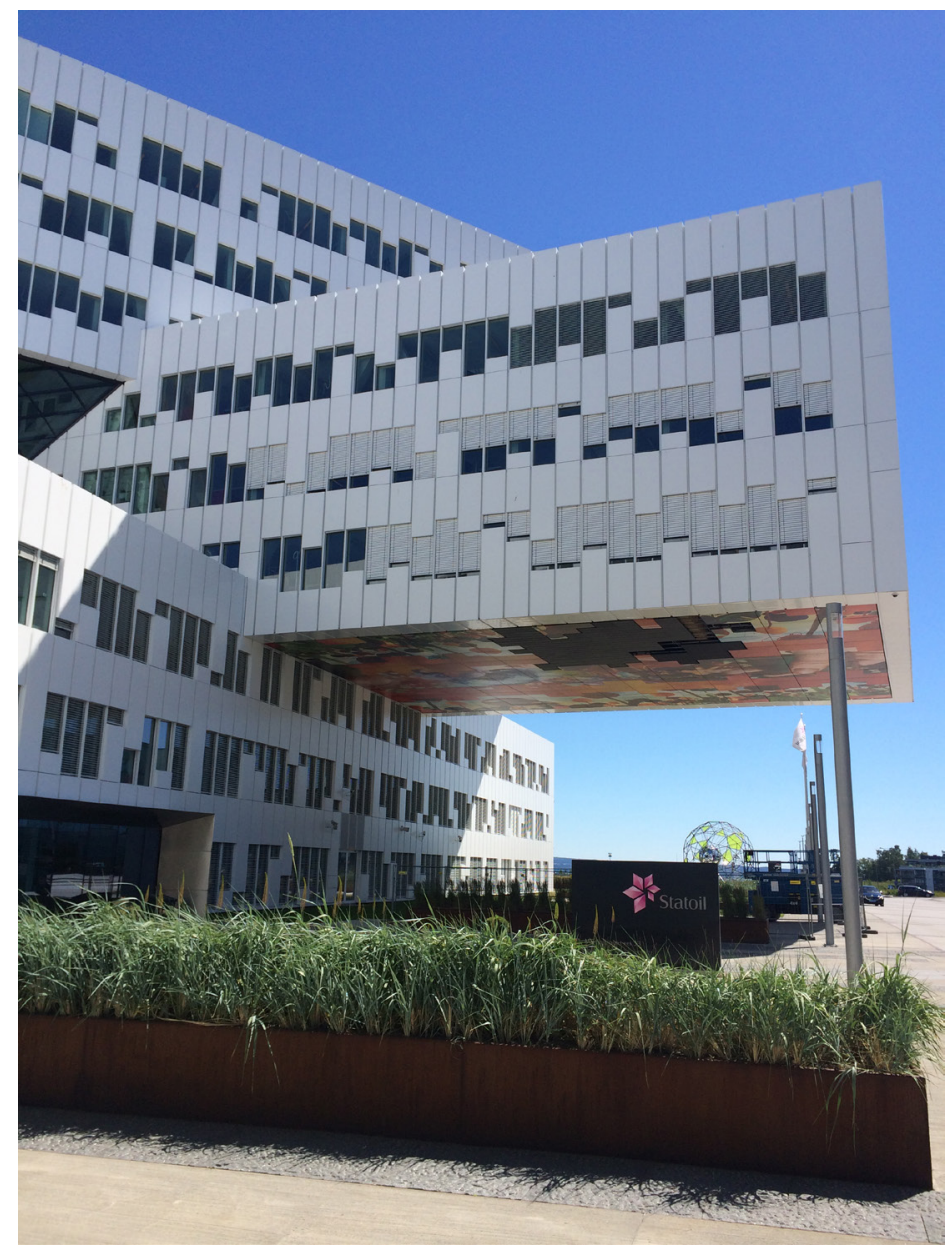

Source: Bjoertvedt/Wikimedia Commons

nature functions as a space that is "hostile to human beings" (Personal correspondence with Annika Pham, 26 August 2017); instead, being isolated from the urban world serves the interests of the Norwegian patriots, forcing their enemies to deal with the elemental power of the Nordic realm. From their forested redoubts, Fritt Norge is able to strike with bloody results conjuring a dark realism within Occupied that reminds the viewer of the 2011 violent attack by Anders Behring Breivik, which removed the myth that Islamists maintain a "macabre exclusivity" on the use of terror in Europe (Moïsi, 2016: loc. 1814).

Regarding the filming locations and scenery, showrunner Erik Skjoldbjærg expressed a desire "to create a universe that would represent a future, yet reference to the past World War" (quoted in Pham, 2015b). The series makes effective use of a colour palette to code geopolitical meaning, especially when it comes to depicting the Russian presence. Ironically, the most central parts of Oslo (i.e., where a tourist is mostly likely to book a hotel or wander about) become dark and foreboding spaces through fanciful camera angles and low lighting, producing the affect of claustrophobia familiar to the regular view of Cold War cinema (cf. Kirchik, 2016a; Shaw, 2007; Van Jelgerhuis, 2015). 
Figure 4. The (fictional) thorium power station

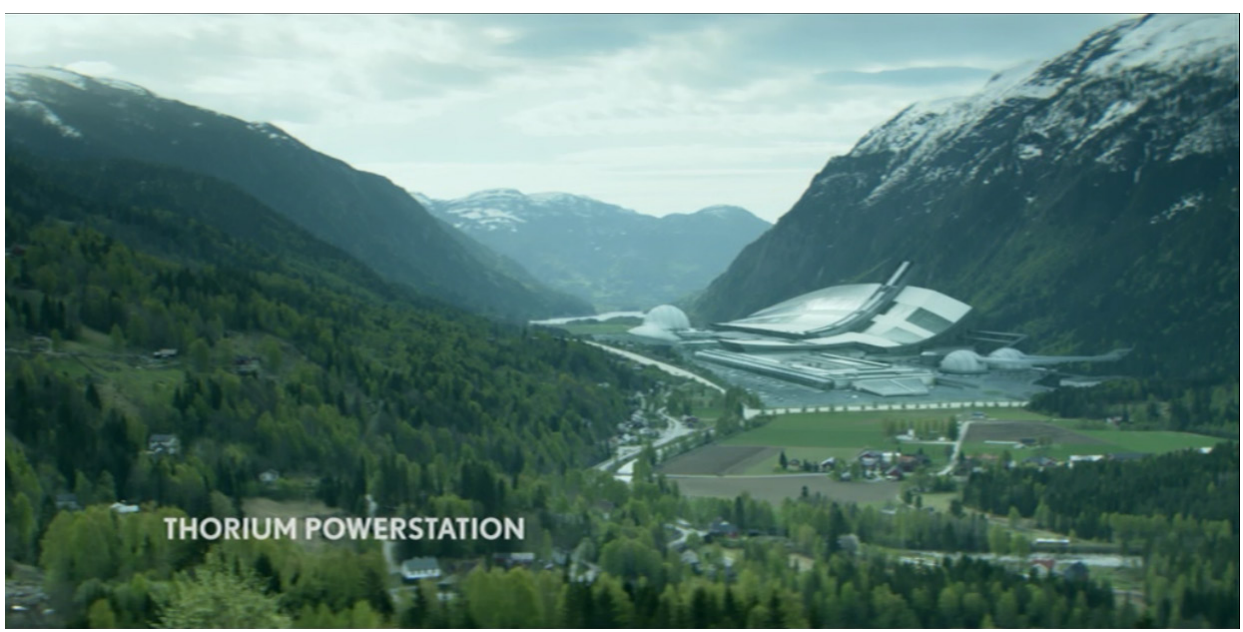

Source: Occupied/Yellowbird

When I interviewed him (18 September 2017) about the use of landscape, Skjoldbjærg stated that he began with a dichotomy between pragmatism and idealism, but when he brought on Danish production designer Niels Sejer Pedersen, this was expanded to form a grid that also included the binaries of tradition and innovation. While this matrix was primarily designed for character development, it also functioned as a handy tool for landscapes and representations of space: the thorium station (see Figure 4) signifies idealistic innovation and the über-modern Statoil building qua the prime minister's office pragmatic innovation, whereas the verdant green spaces of the insurrection leader Harald Vold's (Stig Amdam Ryste) fly-fishing excursions represent idyllic traditions and the snowy borderscapes of the Finnmark-Russia frontier exemplify pragmatic tradition (see Figure 5).

Figure 5. The Russian-Norwegian border

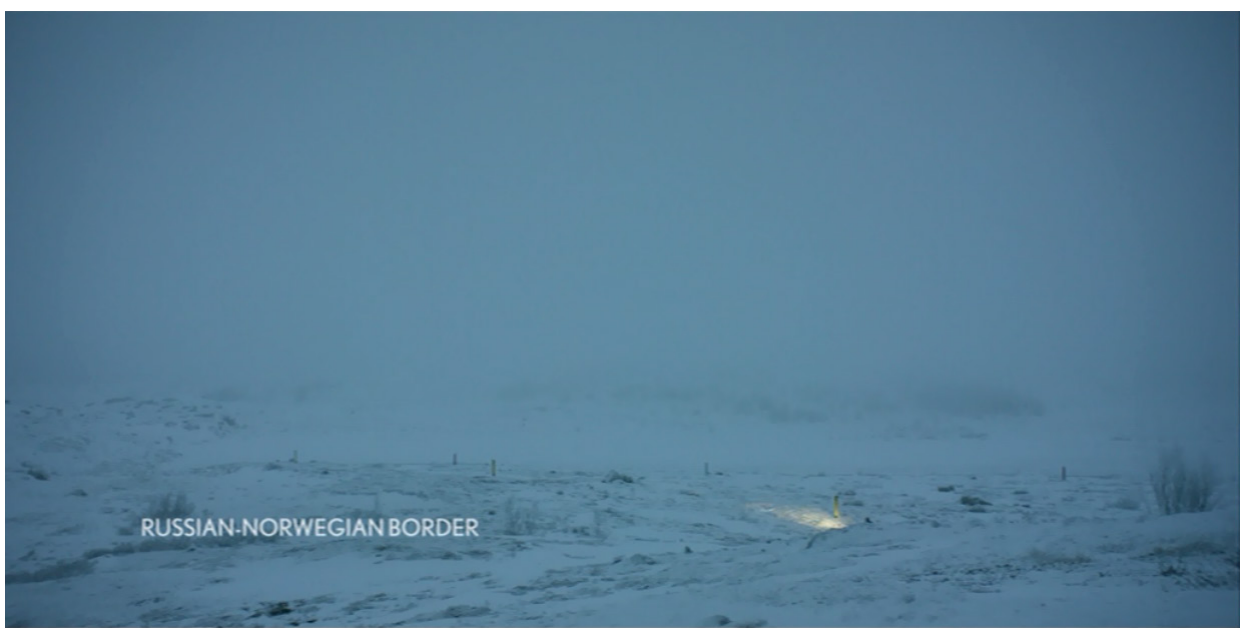

Source: Occupied/Yellowbird 
Regarding the last of these examples, the series reflects Nesbø's well-established fascination with Finnmark, and the region's history of occupation (both Axis and Soviet) during World War II. Indeed, the author has taken pains to disabuse critics that Occupied is a "response" to Russian adventurism in Ukraine, arguing that the inception of the project dates back long before "Little Green Men" began showing in up in Crimea. Despite the "disturbing relevance" of the series, the geopolitics of Occupied are rooted in Norwegian soil, reflecting a land that introduced the surname Quisling into the English language as a noun, synonymous with "traitor" (Kirchik, 2016b). As the show's producer puts it: "Right now, our society in Norway is pretty stable, but by creating a fictitious future, you can play with geopolitics, and see how it would impact individuals and mirror our current world" (Skjoldbjærg quoted in Pham, 2015b). In its use of geopoliticised landscapes, Occupied does just that, from its use of acier, anonymising spaces to represent "Russianness", to its employment of primordial taiga to evoke the purity of "Norwegianness", to its manipulation of satellite imagery and footage of extreme weather events to generate feelings of insecurity associated with the Anthropocene epoch. Yet, as Leyda (2018) points out in her work, in Occupied, as an example of cli-fi, the evocative use of such politicised landscapes - which contrast two oil-rich states (the Russian Federation and Norway) - also mitigates the percolating petro-guilt flowing through Norwegian society.

\section{Nobel - bringing the war home, and turning the world upside down}

Created by Per-Olav Sørensen, the force behind the internationally successful historical drama Kampen om tungtvannet [The Heavy Water War] (2015), Nobel has been described as a "geopolitical conspiracy that ties together oil interests, humanitarian organizations, the Norwegian government and, centrally, an elite Norwegian specialforces unit whose work in Afghanistan involves it in murder and cover-ups back home" (Hale, 2017). Growing out of Sørensen's desire to document his country's involvement in Operation Enduring Freedom, the series received backing from the Norwegian Film Institute and commenced principal photography in 2015 (Pham, 2015a). Between 2001 and 2014, over 9,000 Norwegian military personnel served in Afghanistan, with the loss of ten lives, while the government spent approximately NOK 20 billion (over USD 2.5 billion) on the conflict; today, only about 500 soldiers remain. Norway's participation proved notable for its role as an early interlocutor with the Taliban and its support of Provincial Reconstruction Team (PRT) efforts (Godal, 2016), both of which are showcased in the series.

Nobel ran on NRK, with the 25 September 2016 premiere commanding nearly 800 thousand viewers, or a market share of 45 per cent, and receiving rave reviews from Aftenposten, Dagbladet, and other publications (Pham, 2016). Early distribution deals with Sweden's SVT and Iceland's RÚV followed; global distribution was handled by DRG, with the series premiering on the Netflix platform in mid-December 2016. Like Occupied, the series focuses on a male character, Lieutenant Erling Riiser (Aksel Hennie), and his complicated family life which is imperilled by his lethal actions abroad and at home (his partner Johanne, played by Tuva Novotny, works for the Foreign Ministry and is involved in high-level discussions on energy development in Afghanistan). The couple thus serves as a complex and counterpoised set of Norwegians whose relationship contests and reinforces Norway's heroic role as a humanitær supermakt [humanitarian 
superpower] (Rees, 2016); this tension lays bare the problems of the country's naiveté with regards to its actual impact on the world (despite its well-intentioned interventions in the Global South). Upon his return from a bloody mission in central Asia, the rather naïve Riiser is drawn into a transnational web of revenge and corruption, resulting in his extrajudicial killing of an Afghan warlord in a subterranean parking garage in central Oslo. Riiser soon learns that he is simply a pawn in a much bigger game. As one critic noted: "What the drama is thinking about is the small difference between the extremism in Afghanistan and the extreme capitalism that drives countries and corporations to take advantage of the earth itself" (Doyle, 2016: para. 9).

Reflecting its close attention to military affairs, Nobel opens with a Skype conversation between Riiser, stationed at a forward operating base in northern Afghanistan, and his adolescent son back in Oslo. The scene makes a dramatic transition via a drone-based camera shot, which rises slowly from the base into the night sky, framing the well-lit beige tents of the Norwegian special forces camp in stark contrast to the complete darkness of the surrounding territory. Shortly thereafter, the focus is relocated to Norway, connecting the militarised space of Gardermoen Air Station, to Oslo, to the Riiser family home, a horse farm outside of Oslo. This geographic back-and-forth (which is also temporal, as the events in Afghanistan occur several months before those in Norway, with space and time linking up in the series finale) is a hallmark of the series.

Figure 6. Promotional image of Nobel with a militarised subject

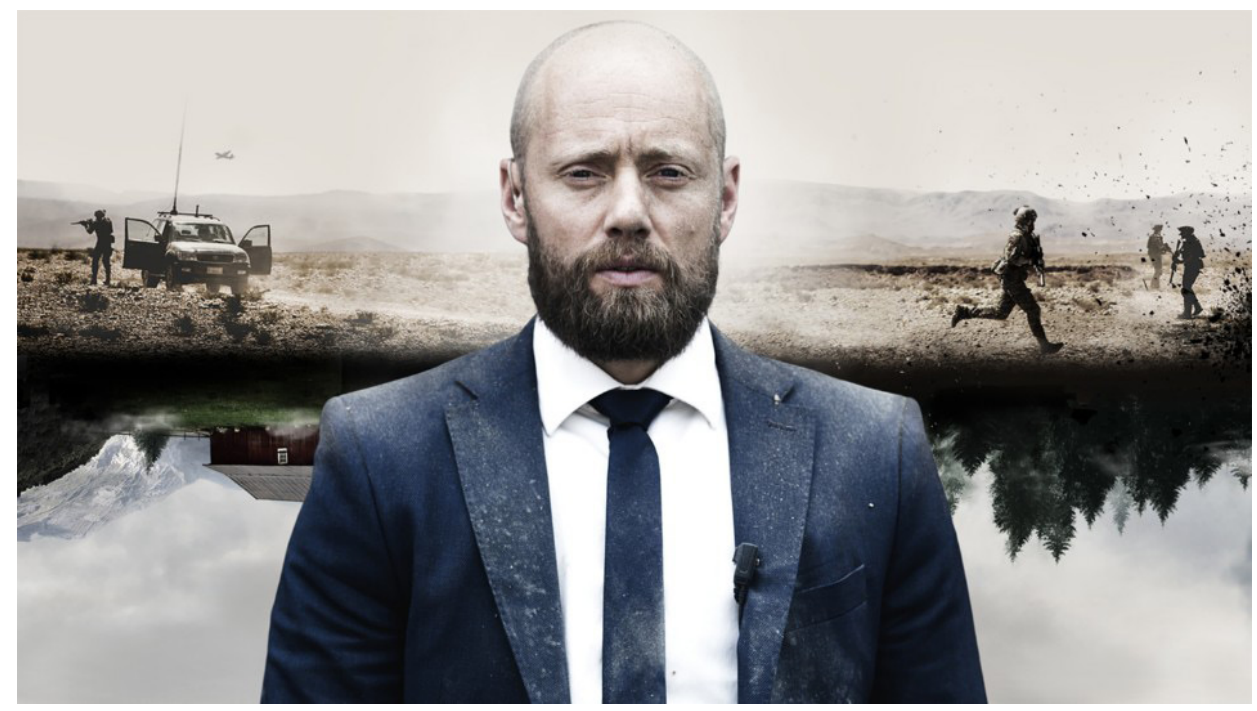

Source: CMonster Scripted

Poignantly, the main advertisement for the series is a split scene of two "worlds": the main character Riiser stands in the middle of the frame, but in the background, we see a war-scape of Afghanistan occupying the upper half (orientated rightside-up) with a Norwegian boreal-scape filling the lower half of the scene (turned upside-down) (see Figure 6). Living things connect both spaces, whether in the form of humans or horses. Indeed, steeds against the landscape figure importantly in the series: a pivotal scene involves a buzkashi match in which Riiser and his close friend Jon Petter (Anders 
Danielsen Lie) vie with their nemesis Sharif Zamani (Atheer Adel) for the glory of carrying a goat carcass across their opponent's field of play, thus linking the soldiers' Norwegian place-pasts to their Afghan place-presents (see Figure 7).

Figure 7. Norwegians vs. Afghans: Horsemanship across the world

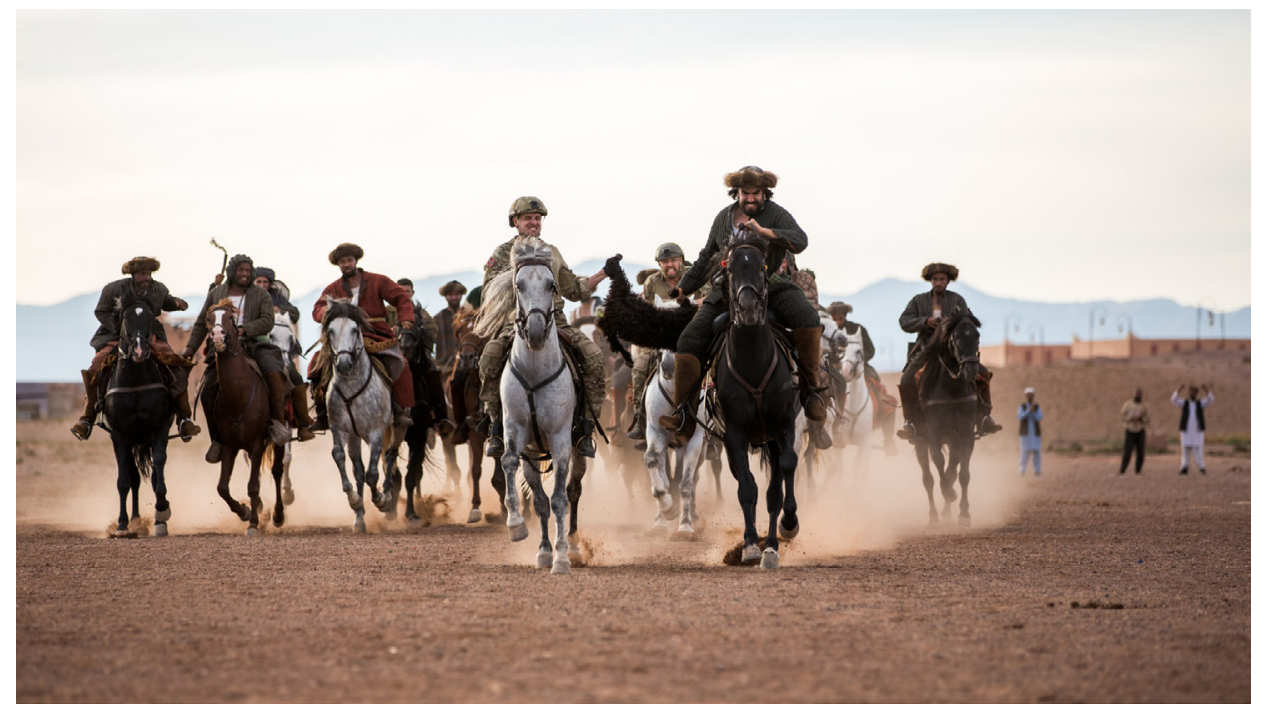

Source: OMonster Scripted/Photo

Credits: Ulf Brantas

Afghanistan is depicted as martial space at all times, even when moments of fleeting calm define the narrative, thus reifying concerns about Norwegian deployments abroad in service of the country's longtime ally, the US; Washington is the absent presence throughout the series with the sole exception of an interchange with a cabinet official who visits Norway to quietly inquire about the possibility of opening talks with the Taliban. The visual rhetoric of Nobel relies heavily on its colour palette and landscape depictions to establish (b)orders between here and there, in other words, the homely, familiar (Norway) and the uncanny, othered (Afghanistan). According to Pottie-Sherman and Wilkes (2016: 82):

Visual media have long been instrumental in the production of international borders as sites of spectacle. Often far from physical boundaries, these representations of the "geographical imaginations" of Otherness and belonging are germane to our understanding of contemporary nation-building projects.

However, with digital media convergence, the very meaning of "borders" is collapsing upon itself, as suggested both by the series-opening Skype call and the various scopings and scapings of two "worlds" which are inextricably linked through the masculine, militarised body of Riiser. Not insignificantly, Riiser is tricked into killing an Afghan warlord in Norway via a text message from a hacked mobile account which he believes is an order coming from his commanding officer. Additionally, the viewer frequently gazes at the Afghan people from Riiser's perspective, and more specifically through the scope of his sniper's rifle. 
As referenced above, these dusty, violent settings are jarringly contrasted against green and grey zones of patriotism, stability, and family as the Riiser family attends a medal ceremony within the gates of thirteenth-century Akershus Fortress. ${ }^{3}$ However, just as the viewer settles into a scopic regime defined by the well-funded Nordic welfare state, immaculate urbanscapes, and a verdant countryside, they are unceremoniously transported to the battlefield, a vast, desolate, and harsh world that hides danger in plain sight/site. The bodily nexus that links Norway to Afghanistan is Zamani's wife Wasima (Ayesha Wolasmal). Due to a series of banal social encounters and byzantine geopolitical machinations, she becomes tethered to the Norwegian special forces, who rescue her from her husband and transport her back to their homeland, thus shifting the brown female body from a (familiar) hostile environment to a (unfamiliar) milieu of promised security. However, even Norden cannot protect this unfortunate soul, as she is kidnapped and brutalised by her husband, forcing Riiser's hand. Using the skills he has learned in the service, he violently dispatches the loathsome Zamani. Yet, this action only thickens the temporal and territorial bonding of Afghanistan and Norway, collapsing the distance between Oslo and Mazar-i-Sharif. As the series progresses, the visual fluctuation increases in speed and intensity. Interruptions of the narrative with landscape depictions isolates the gaze of the viewer. Contra Lefebvre (2007a), who claims this frees the object (in this case a landscape) from its narrative function, I contend that geopolitically charged panoramas actually buttress the storytelling capacities of televisual dramas, serving as foreground rather than background. Nobel constantly toggles back and forth between the beige, desert realms of "Afghanistan" (i.e., Morocco) ${ }^{4}$ and the green, leafy vistas of Norway, a dualistic scopic regime that is only enhanced by the depiction of sleek Scandinavian buildings contrasted against the decrepit hovels and cement compounds of (an imagined) central Asia (see Güney \& Gökcan, 2010).

In his chapter in Landscape and Film, Lefebvre links the concepts of landscape and territory, reminding us that maps and artistic representation of places exist in a perpetually reinforcing relationship that enables us to "visually apprehend some stretch of real space" (2007a: 51). In Nobel, affectual landscapes are brought to bear in a fairly methodical way, scaping views of the Norwegian heimat against a distant and dangerous land. Ultimately, it does not matter that such vistas are filmed in Morocco and not inner Asia, as the implied purpose is to present a landscape of extreme otherness. In doing so, Nobel echoes a vast array of hoary us-versus-them-based cultural productions that make use of the Oriental Other (see Said, 1978). However, via the cinematic and increasingly televisual tool of scoping the object that is to be gazed at, we see an additional layering of geopolitics on the mapping of the outside world through the literal and figurative lens of surveillance (cf. Dodds, 2011; Zimmer, 2015). In its narrative logic, this series achieves its goal of documenting (or more accurately representing) the experience of Norwegian soldiers in the Afghanistan theatre; however, via its usage of geopolitically inflected landscapes - particularly those which are confined to summertime screenings, or seeings, of Norway - it presents a binary realm that echoes back across the centuries of east-west military engagement and civilisational conflict, therein obfuscating a greater accumulate of peaceful coexistence and cultural synthesis. ${ }^{5}$ 


\section{Conclusion: Norwegian landscape in the frame of geopolitics}

As the other articles in this special issue attest, Nordic television drama is highly attuned to questions of (geo)politics. Drawing on a tradition that began as a Marxist indictment of the faltering welfare state (cf. Forshaw, 2012; Nestingen \& Arvas, 2011; StougaardNielsen, 2017) and which has evolved through different media (including cinema and television series), Nordic Noir has something to say about the state of the world (and the region's place within it). In this article, I have focused on a single aspect of this type of storytelling, namely the visual rhetoric of screened landscapes in two Norwegian nearnoir dramas, Occupied and Nobel. These two series exhibit a number of commonalities, both with respect to narrative and production, distribution, and reception. In terms of content, shared aspects include posing critical questions about Norway's dependence on oil, fears about threats to national sovereignty, a problematisation of military-civilian relations, and what it means to be Norwegian in the twenty-first century. However, it is important to bring attention to key differences between these two series, particularly given that both have been consumed around the globe via Netflix, often by viewers who have little knowledge of Norway beyond its top-notch reputation (De Carvalho \& Sande Lie, 2014) and image as the land of fjords (Norberg-Schulz, 1996).

Bringing geopolitics into the frame, Occupied and Nobel offer two rather different frameworks for exploring Norway's place in world affairs. Indeed, the former draws on a well-established tradition of late Cold War filmic representation including the political thrillers Orions belte [Orion's Belt] (1985) and Etter Rubicon [After Rubicon] (1987), while also engaging with still-raw themes of national loyalty versus expedient opportunism surrounding the country's occupation by Nazi Germany during World War II. However, as a work of speculative fiction set in the near future, Nesbø's vision offers a "could-be" narrative for Norway in a time of shifting geopolitical realities initiated by the Trump Administration. While Occupied is both backward- and forward-looking, Nobel is decidedly presentist in orientation, serving as a barometer of contemporary issues associated with Norway's complicated status as a humanitarian superpower on the one hand, and a wily operator in the field of petro-politics on the other, thus rhyming with such critical geopolitical cinema associated with the so-called Global War on Terror as the Hollywood productions of Lions for Lambs (2007), In the Valley of Elah (2007), and Rendition (2007) (see Dodds, 2008). On its surface, the series presents as a military drama; however, upon closer inspection, Nobel mimics the pacing and intrigues of Nordic Noir fare quite effectively, ultimately unravelling a complicated yarn of political intrigue, corporate greed, compromised values, and individual failings.

Despite their common depictions of Norwegian (and other) landscapes, these two series diverge markedly. Occupied draws on cinematic aesthetic traditions of anti-Soviet and Russophobic representation (Mrozewicz, 2018; Saunders, 2017; Shaw, 2007) and the Arctic realm as a zone of death and danger (cf. Dodds, 2018; MacKenzie \& Westerstahl Stenport, 2015); conversely, Nobel's mediascaping of an idyllic blue-green Norway against a dangerous beige-brown "Afghanistan" is reminiscent of hundreds of Orientalist films going back to the dawn of the medium (cf. Kellner, 2011; McAlister, 2005; Shaheen, 2001). Yet despite differences in the visual rhetoric of these two series, it is not impossible to reassemble a geopolitical imago of contemporary Norway, a seemingly secure country under siege from without and within, but one which will overcome due to its traditional values of fairness, propriety, and a love of nature. 
In terms of their production, both series proved to be expensive, high-quality productions that captured large audiences at home and abroad via international distribution platforms such as Netflix and over-the-air broadcasts in a number of countries around Europe. Knitting these together is landscape, which both series use as a narrative tool and as a strategy for making these shows alluring, meaningful, and ultimately successful. The geographer Denis Cosgrove (1984: 35) reminds us: "Landscape is to be judged as a place for living and working in terms of those who actually do live and work there. All landscapes are symbolic [emphasis original]". In Occupied and Nobel, we see explicit use of iconic vistas of Norway and those natural and human-built geographies which define the state and its people. From Vold's fly-fishing pond to the Riiser family's horse farm to the use of Akershus Fortress in both series, Norway is screened in a symbolic and ideological way that continues to reify what it means to be Norwegian. Returning to my cartographic theme, the use of landscape in television series both produce and map space, in its lived, conceived, and perceived forms (Lefebvre, 1991). Geopolitically inclined series such as Nobel and Occupied, while developed for a national audience (in this case, Norway), benefit from evolving global distribution platforms that propel these dramas far beyond the countries in which they are produced. While these series continue the tradition of employing popular culture as a tool for national identity-building, especially via their place-based imagery that speaks to pressing questions of geopolitics, such performances of national quiddity inevitably become internationalised, therein serving to complicate how Norwegians see themselves and how they are seen by those beyond the country's borders.

\section{Notes}

1. In Irish, we find the derivative term tirdhreach, a compound of "land" and "scenery", akin to the Welsh tirwedd or "land appearance," whereas in Finnish maisema is compound of "land" and "view". However,

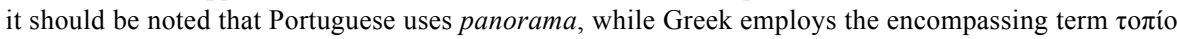
which translates as "scenery", both of which go some way in bringing the gaze into the conceptional construct.

2. The development of the element as a sustainable resource is not particularly outlandish. As the World Nuclear Association (2019) website states: "The use of thorium as a new primary energy source has been a tantalizing prospect for many years. Extracting its latent energy value in a cost-effective manner remains a challenge, and will require considerable $R \& D$ investment. This is occurring pre-eminently in China, with modest US support”.

3. It should be noted that the fortress features quite prominently in both case studies. Having withstood a number of attacks from abroad over its existence, the site/sight supports the visual rhetoric of Norway as a plucky survivor, fiercely independent, even when under foreign rule.

4. Morocco has been labelled "Africa's little Hollywood" (see Morlin-Yron, 2017) for the government's openness to filming, as well as its vistas, which serve as "safe" stand-ins for a variety of locales associated with the greater Middle East (e.g., Saudi Arabia, Jordan, Iraq, Pakistan, etc.).

5. A rather banal rejoinder to the claim that Scandinavia is the antithesis of the Muslim world came in 2018 when Sweden.Se, the nation's official twitter account declared that the national dish (i.e., Swedish meatballs) was in fact of Turkish origin, sending ultra-right-wing nationalists into a rage.

\section{Acknowledgements}

I would like thank Anne Marit Waade and Anna Mrozewicz for their helpful comments on drafts of the essay, as well as the valuable feedback provided by the referees. I also express my gratitude to Gabriella Calchi Novati for encouraging me to expand the scope of the analysis, particularly in regards to issues of Anthropocene studies. 
Landscape, geopolitics, and national identity in the Norwegian thrillers Occupied and Nobel

\section{References}

Agnew, J. A. (1998). Geopolitics: Re-visioning world politics. New York: Routledge. https://doi. org/10.4324/9780203413739

Appadurai, A. (1996). Modernity at large: Cultural dimensions of globalization. Minneapolis: University of Minnesota Press.

Booth, M. (2015). The almost nearly perfect people: Behind the myth of the Scandinavian utopia. New York: Picador.

Bos, D. (2018). Answering the Call of Duty: Everyday encounters with the popular geopolitics of militarythemed videogames. Political Geography, 63, 54-64. https://doi.org/10.1016/j.polgeo.2018.01.001

Cohen, S. B. (2003). Geopolitics of the world system. Lanham, Maryland: Rowman \& Littlefield.

Cosgrove, D. E. (1984). Social formation and symbolic landscape. Madison: University of Wisconsin Press. Davidson, P. (2005). The idea of the north. London: Reaktion Books.

De Carvalho, B., \& Sande Lie, J. H. (2014). A great power performance: Norway, status and the policy of involvement. In B. De Carvalho, \& I. B. Neumann (Eds.), Small state status seeking: Norway's quest for international standing (pp. 56-72). London: Routledge. https://doi.org/10.4324/9781315758817

DeLue, R. Z., \& Elkins, J. (Eds.). (2008). Landscape theory. New York: Routledge. https://doi. org/10.4324/9780203929834

Dodds, K. (2008). Hollywood and the popular geopolitics of the war on terror. Third World Quarterly, 29(8), 1621-1637. https://doi.org/10.1080/01436590802528762

Dodds, K. (2011). Gender, geopolitics, and surveillance in The Bourne Ultimatum. Geographical Review, 101(1), 88-105. https://doi.org/10.1080/01956050903450895

Dodds, K. (2018). Ice: Nature and culture. London: Reaktion Books.

Doyle, J. (2016). If you like Nordic Noir, watch Nobel - Peace at Any Price. The Globe and Mail. https:// www.theglobeandmail.com/arts/television/john-doyle-if-you-like-nordic-noir-watch-nobel-peace-atany-price/article33322344/

Drezner, D. W. (2016). You should watch the best show about international relations on television right now. Washington Post. https://www.washingtonpost.com/posteverything/wp/2016/2002/2019/youshould-watch-the-best-show-about-international-relations-on-television-right-now/?utm_term=. cf2018e0109b2057c

Dyer-Witherford, N., \& De Peuter, G. (2008). Armed vision and the banalization of war: Full Spectrum Warrior. In J. Marchessault, \& S. Lord (Eds.), Fluid screens, expanded cinema (pp. 316-327). Toronto: University of Toronto Press.

Dyson, S. B. (2015). Otherworldly politics: The international relations of Star Trek, Game of Thrones, and Battlestar Galactica. Baltimore: Johns Hopkins University Press.

Dyson, S. B. (2018). In the tv thriller 'Occupied,' Russia has western democracy on the run. Washington Post. https://www.washingtonpost.com/news/monkey-cage/wp/2018/2003/2019/in-the-tv-thriller-occupiedrussia-has-western-democracy-on-the-run/?utm_term $=.5871$ cec 28507

Eichner, S., \& Waade, A. M. (2015). Local colour in German and Danish television drama: Tatort and Bron/ Broen. Global Media Journal (German Edition), 5(1), 1-20.

Ellis, J. (2018, June 6). Trends: Producing drama -for international or domestic markets? [Conference presentation]. Transnational Television Drama: Tastes, Travels, and Trends, University of Aarhus, Denmark.

Elviken, A. (1931). The genesis of Norwegian nationalism. The Journal of Modern History, 3(3), 365-391.

Forshaw, B. (2012). Death in a cold climate - A guide to Scandinavian crime fiction. Basingstoke, UK: Palgrave MacMillan.

Fuglestad, E. M. (2018). The nation as propertied community: The emergence of nationalism in the United States and Norway. Studies in Ethnicity and Nationalism, 18(3), 237-261. https://doi.org/10.1111/ sena. 12281

Fyhri, A., Steen Jacobsen, J. K., \& Tømmervik, H. (2009). Tourists' landscape perceptions and preferences in a Scandinavian coastal region. Landscape and Urban Planning, 91(4), 202-211. https://doi.org/10.1016/j. landurbplan.2009.01.002

Glynn, K., \& Cupples, J. (2015). Negotiating and queering US hegemony in TV drama: Popular geopolitics and cultural studies. Gender, Place \& Culture: A Journal of Feminist Geography, 22(2), 271-287. https:// doi.org/10.1080/0966369X.2013.855711

Godal, B. T. (2016). En god alliert - Norge i Afghanistan 2001-2014 [A good ally - Norway in Afghanistan]. Oslo: Departementenes sikkerhets- og serviceorganisasjon Informasjonsforvaltning.

Güney, A., \& Gökcan, F. (2010). The "greater Middle East" as a "modern" geopolitical imagination in American foreign policy. Geopolitics, 15(1), 22-38. https://doi.org/10.1080/14650040903420370

Gunnarsson, T. (1998). Nordic landscape painting in the nineteenth century. New Haven: Yale University Press. Hains, T. (2016). Trump: NATO is obsolete and expensive, "doesn't have the right countries in it for terror- 
ism”. Real Clear Politics. https://www.realclearpolitics.com/video/2016/03/27/trump_europe_is_not_ safe_lots_of the free_world_has_become_weak.html

Hale, M. (2017). On Netflix, the borders remain open. New York Times. https://www.nytimes.com/2017/03/13/ arts/television/netflix-fauda-nobel-review.html

Hansen, K. T., \& Waade, A. M. (2017). Locating Nordic Noir: From Beck to The Bridge. Cham: Palgrave Macmillan. https://www.doi.org/10.1007/978-3-319-59815-4

Harper, G., \& Rayner, J. (2010). Cinema and landscape: Film, nation and cultural geography. Chicago: Intellect.

Herwig, H. H. (2016). The demon of geopolitics: How Karl Haushofer "educated" Hitler and Hess. Lanham, Maryland: Rowman \& Littlefield.

Høyem, S. (2015). Black \& gold [Song]. On Black \& gold. Hektor Grammofon.

Jay, M. (1988). Scopic regimes of modernity. In H. Foster (Ed.), Vision and visuality (pp. 3-23). Seattle: Bay Press.

Kellner, D. M. (2011). Cinema wars: Hollywood film and politics in the Bush-Cheney Era. New York: John Wiley \& Sons. https://www.doi.org/10.1002/9781444314809

Kiersey, N. J., \& Neumann, I. B. (Eds.). (2013). Battlestar Galactica and international relations. London: Routledge. https://doi.org/10.4324/9780203070055

Kirchik, J. (2016a). Cold War nostalgia: What German television tells us about today's Europe. Weekly Standard. http://www.weeklystandard.com/cold-war-nostalgia/article/2002366\#

Kirchik, J. (2016b). The Norwegian TV series that's enraged the Kremlin. Politico. http://www.politico.eu/ article/occupied-norwegian-tv-series-thats-enraged-the-kremlin-norway-russia-occupation/

Lefebvre, H. (1991). The production of space. Cambridge: Blackwell.

Lefebvre, M. (2007a). Between landscape and setting in the cinema. In M. Lefebvre (Ed.), Landscape and film (pp. 19-60). London: Routledge.

Lefebvre, M. (Ed.) (2007b). Landscape and film. London: Routledge. https://doi.org/10.4324/9780203959404

Leyda, J. (2018). Petropolitics, cli-fi and Occupied. Journal of Scandinavian Cinema, 8(2), 83-101. https:// doi.org/10.1386/jsca.8.2.83_1

Lowenthal, D. (1982). Revisiting valued landscapes. In J. R. Gold, \& D. Burgess (Eds.), Valued environments (pp. 74-99). London: Allen \& Unwin.

Lukinbeal, C. (2005). Cinematic landscapes. Journal of Cultural Geography, 23(1), 3-22. https://doi. org/10.1080/08873630509478229

MacKenzie, S., \& Westerstahl Stenport, A. (2015). Films on ice: Cinemas of the Arctic. Edinburgh: Edinburgh University Press.

McAlister, M. (2005). Epic encounters: Culture, media, and U.S. interest in the Middle East since 1945. Berkeley: University of California Press.

McElroy, R., \& Noonan, C. (2019). Producing British television drama: Local production in a global era. London: Palgrave Macmillan.

Melton, M. (2016). Bear lurking in the fjords: Review of TV2's Occupied. Providence. https://providencemag. com/2016/03/bear-lurking-fjords-review-tv2-occupied-okkupert/

Metz, C. (1982). The imaginary signifier: Psychoanalysis and the cinema. Bloomington: Indiana University Press.

Mitchell, W. J. T. (2002). Landscape and power. Chicago: University of Chicago Press.

Moïsi, D. (2016). La géopolitique des séries ou le triomphe de la peur [The geopolitics of series or the triumph of fear]. Paris: Stock.

Morlin-Yron, S. (2017). Why Morocco is Africa's little Hollywood. CNN. https://edition.cnn.com/2016/11/07/ africa/morocco-hollywood-films/index.html

Mrozewicz, A. E. (2018). Beyond Eastern noir: Reimaging Russia and Eastern Europe in Nordic cinemas. Edinburgh: Edinburgh University Press.

Nestingen, A., \& Arvas, P. (Eds.). (2011). Scandinavian crime fiction. Cardiff: University of Wales Press.

Norberg-Schulz, C. (1996). Nightlands: Nordic building. Cambridge, Massachusetts: MIT Press.

Olwig, K. R. (2004) "This is not a landscape": Circulating reference and land shaping. In H. Palang, H. Sooväli, M. Antrop, \& G. Setten (Eds.) European rural landscapes: Persistence and change in a globalising environment (pp. 41-66). Dordrecht: Kluwer.

Ó Tuathail, G. (1996). Critical geopolitics. Abingdon, UK: Taylor \& Francis. https://doi.org/10.4324/9780203973059

Pham, A. (2015a). Aksel Hennie stars in high end Nobel TV drama. Nordisk Film \& TV Fond. http://www. nordiskfilmogtvfond.com/news/stories/aksel-hennie-stars-high-end-nobel-tv-drama/

Pham, A. (2015b). Erik Skjoldbjærg: "Occupied questions how people would react to radical change." Nordisk Film \& TV Fond. http://www.nordiskfilmogtvfond.com/news/stories/erik-skjoldbjaerg-occupiedquestions-how-people-would-react-radical-change

Pham, A. (2016). Nobel director: I love getting into people's head and creating drama that is both personal 
and entertaining. Nordisk Film \& TV Fond. http://www.nordiskfilmogtvfond.com/news/interview/nobeldirector-i-love-getting-into-peoples-head-and-creating-drama-that-is-both-personal-and-entertaining

Pottie-Sherman, Y., \& Wilkes, R. (2016). Visual media and the construction of the benign Canadian border on National Geographic's Border Security. Social \& Cultural Geography, 17(1), 81-100. https://doi. org/10.1080/14649365.2015.1042400

Rapoza, K. (2017). Norwegian TV series 'Occupied' hints At U.S. leaving NATO, and Russia invading. Forbes. https://www.forbes.com/sites/kenrapoza/2017/10/01/norwegian-tv-series-occupied-hints-at-u-s-leavingnato-and-russia-invading/\#79b03bbf771e

Redvall, E. (2016). The concept of “double storytelling” in Danish public TV drama. In S. Maras (Ed.), Ethics in screenwriting: New perspectives (pp. 33-54). London: Palgrave Macmillan.

Rees, E. (2016). Privilege, innocence, and "petro-guilt" in Maria Sødahl's Limbo. Scandinavian Studies, 88(1), 42-59. https://10.5406/scanstud.88.1.42

Roberts, L. (2012a). Cinematic cartography: Projecting place through film. In L. Roberts (Ed.), Mapping cultures: Place, practice, performance (pp. 68-84). Houndsmills, UK: Palgrave Macmillan.

Roberts, L. (2012b). Film, mobility and urban space - a cinematic geography of Liverpool. Liverpool: Liverpool University Press.

Roberts, L. (2016). Landscapes in the frame: Exploring the hinterlands of the British procedural drama. New Review of Film and Television Studies, 14(3), 364-385. https://doi.org/10.1080/17400309.2016.1189712

Said, E. (1978). Orientalism. New York: Vintage Books.

Saunders, R. A. (2017). Popular geopolitics and nation branding in the post-Soviet realm. New York: Routledge. https://doi.org/10.4324/9781315737386

Saunders, R. A. (2019a). Geopolitical television at the (b)order: Liminality, global politics, and world-building in The Bridge. Social \& Cultural Geography, 20(7), 981-1003. https://doi.org/10.1080/14649365.20 17.1404122

Saunders, R. A. (2019b). Small screen IR: A tentative typology of geopolitical television. Geopolitics, 24(3), 691-727. https://doi.org/10.1080/14650045.2017.1389719

Shaheen, J. (2001). Reel bad Arabs: How Hollywood vilifies a people. New York: Olive Branch Press.

Shaw, T. (2007). Hollywood's cold war. Amherst, Massachusetts: University of Massachusetts Press.

Stougaard-Nielsen, J. (2017). Scandinavian crime fiction. New York: Bloomsbury.

Telegraph, T. (2017). From Wallander to A Very Secret Service: The 10 best foreign TV shows on Netflix. The Telegraph. http://www.telegraph.co.uk/on-demand/0/the-best-foreign-drama-shows-on-netflix/ occupied--okkupert-norway/

Turner, G., van Zoonen, L, \& Harvey, J. (2014). Confusion, control and comfort: Premediating identity management in film and television. Information, Communication \& Society, 17(8), 986-1000. https://doi.or $\mathrm{g} / 10.1080 / 1369118 X .2013 .870592$

Van Jelgerhuis, D. (2015). Resurgence of cold war imagery in western popular culture. Tallahassee, Florida: Florida State University.

Wolcott, J. (2016). The Norwegian thriller that predicts the disaster of Trump's geopolitical outlook. Vanity Fair. https://www.vanityfair.com/hollywood/2016/07/occupied-norwegian-thriller-netflix-donald-trump

Woodward, R. (2014). Military landscapes: Agendas and approaches for future research. Progress in Human Geography, 38(1), 40-61. https://doi.org/10.1177/0309132513493219

Woolridge, A. (2013a). Northern lights (Special report: The Nordic countries). The Economist. https://www. economist.com/news/special-report/21570840-nordic-countries-are-reinventing-their-model-capitalismsays-adrian

Woolridge, A. (2013b). Norway: The rich cousin. (Special report: The Nordic countries). The Economist. https://www.economist.com/special-report/2013/01/31/the-rich-cousin

World Nuclear Association. (2019). Thorium. Retrieved August 20, 2019, from http://www.world-nuclear. org/information-library/current-and-future-generation/thorium.aspx

Zimmer, C. (2015). Surveillance cinema. New York: New York University Press.

Copyright: (C) 2020 The Author(s) and Nordicom. This is an Open Access article distributed under the terms of the Creative Commons Attribution 4.0 International License (CC BY-NC-ND 4.0). 